\title{
STRATEGI PEMBANGUNAN PERTANIAN DAN PEREKONOMIAN PEDESAAN MELALUI KEMITRAAN USAHA BERWAWASAN AGRIBISNIS
}

\author{
Oleh \\ Cut Gustiana, SP, M.Agr \\ Dosen Tetap Prodi Agribisnis Fakultas Pertanian \\ Universitas Samudra \\ Langsa
}

Ringkasan

Strategi Pembangunan Pertanian dan Perekonomian Pedesaan Melalui Kemitraan Usaha Berwawasan Agribisnis. Tujuan penulisan Karya IImiah ini untuk (1) Membahas profil ekonomi pedesaan sebagai basis perencanaan program pengembangan, (2) Membahas strategi dasar pembangunan pedesaan berwawasan agribisnis, dan (3) Merumuskan kebijaksanaan pengembangan agribisnis secara koprehensif dan integratif. Proses pembangunan (ekonomi) suatu bangsa secara implisit mensyaratkan adanya transformasi pertanian tradisional menjadi pertanian maju atau modern. Dalam proses transformasi itulah pola partisipasi memainkan peranannya. Pertanian maju adalah pertanian yang berkemampuan untuk terus-menerus menyesuaikan diri dengan tantangan dan permintaan pasar yang senantiasa berubah. Kelembagaan kemitraan usaha agribisnis yang dapat mengeliminir berbagai kegagalan tersebut adalah kelembagaan usaha agribisnis terpadu, berupa keterpaduan antarpelaku (petani, pedagang, pengolah) dan produk (bahan baku berkualitas, penanganan pascapanen yang prima serta jaminan keamanan pangan). Model tersebut didukung oleh revitalisasi kelembagaan kelompok tani, penyuluhan pertanian, dan perusahaan mitra.

Kata Kunci: Strategi, Pembangunan, Pertanian, Pedesaan, Agribisnis

PENDAHULUAN

Latar belakang

Pembangunan pertanian dalam tiga dasawarsa terakhir lebih difokuskan pada pengembangan komoditas primer dengan mengandalkan kelimpahan sumberdaya alam. Untuk beberapa komoditas telah terjadi pelandaian pencapaian produktivitas karena keterbatasan potensi teknologi. Dilain pihak juga terjadi variasi inefisiensi teknologi pada berbagai wilayah dengan karakteristik yang berbeda. Pada kedua kasus ini peranan teknologi menjadi sangat penting, yaitu teknologi yang mendorong tingkat produktivitas lebih tinggi dan bersifat spesifik lokasi.

Pengembangan komoditas pertanain ke depan perlu didukung oleh sumberdaya kapital, teknologi maju, dan sumberdaya manusia terampil berwawasan agribisnis dan berkelanjutan. Pengembangan paradigma baru ini hendaknya dilaksanakan dalam konteks pemabangunan wilayah, berbasis komunitas lokal dan sejalan dengan pelaksanaan desentralisasi dan otonomi daerah. Melalui pendekatan ini diharapkan akan terjadi keberlanjutan pelaksanaan program pembangunan karena adanya dukungan partisipasi masyarakat luas, terdapat sinergi antar subsistem agribisnis, antar sektor pembangunan, dan antar wilayah desa-kota (agropolitan). Melalui model pengembangan agribisnis ini akan terjadi peningkatan daya saing, nilai tambah, nilai tukar dan kesejahteraan petani.

Usaha tani di Indonesia didominasi oleh usaha tani keluarga skala kecil yang sangat lemah dalam berbagai bidang, seperti keterbatasan dalam menguasai asset produktif, modal kerja, posisi tawar-menawar dan kekuatan politik ekonomi, sehingga tidak dapat berkembang mandiri secara dinamis. Petani kecil sangat tergantung pada golongan petani lahan luas atau pedagang untuk memperoleh asset produktif (lahan, peralatan), modal kerja dan perolehan sarana produksi. Demikian juga dalam penjualan hasil petani sangat tergantung pada pedagang hasil. Oleh karena itu, upaya pemberdayaan petani melalui pengembangan kelompok tani dan melalui kemitraan usaha agribisnis konsolidatif sebagai langkah strategis.

Petani adalah pelaku utama yang harus diberdayakan. Tahap awal yang perlu ditempuh untuk memberdayakan petani adalah membentuk kelembagaan berupa kelompok tani yang merupakan organisasi kerja sama. Kerjasama sangat diperlukan untuk menghadapi berbagai permasalahan yang dihadapi yang pada dasarnya sangat sulit bila dihadapi secara individu. Selama ini petani lemah dalam menentukan harga produksinya karena sulit mendapat akses informasi pasar. Dalam hal ini petani harus melakukan konsolidasi yang bersifat horizontal. Selanjutnya melalui penyuluhan (pendidikan dan latihan) yang berkelanjutan terhadap kelompok yang mendapat pembinaan tersebut diharapkan menghasilkan sumberdaya manusia petani yang memiliki pengetahuan dan keterampilan dalam berusaha tani.

Untuk dapat berusaha tani lebih teratur dan terarah maka kelembagaan kelompok tani perlu menjalin kerja sama dan kemitraan dengan pihak luar/usahawan. Keterkaitan dan kerja sama kelembagaan kelompok tani dengan pihak swasta/usahawan dapat terjalin secara baik bila 
terdapat saling ketergantungan dan kerjasama yang bersifat simetri serta saling menguntungkan.

Peran pemerintah melalui berbagai kebijakan dan program diharapkan dapat mendorong dan menciptakan iklim usaha yang kondusif dan menggairahkan petani/kelompok tani maupun pihak swasta/usahawan, sehingga agribisnis dapat berkembang. Dalam hal ini pemerintah bertindak sebagai fasilitator, regulator, motivator yang harus menserasikan hubungan antar pelaku agribisnis tersebut, sehingga para pelaku dapat berinteraksi secara proporsional dan tidak terjadi eksploitasi yang bersifat kontradiktif. Para pelaku usaha bisa meraih keuntungan yang seimbang. Dengan terjadinya keterpaduan berbagai unsur tersebut (kelompok tani, swasta/usahawan dan pemerintah) diharapkan agribisnis yang bersifat konsolidatif vertikal atau kemitraan tersebut dapat berkembang.

\section{Rumusan Masalah}

1) Profil ekonomi pedesaan sebagai basis perencanaan program pengembangan,

2) Strategi dasar pembangunan pedesaan berwawasan agribisnis, dan

3) Kebijaksanaan pengembangan agribisnis secara koprehensif dan integratif.

\section{Tujuan Penulisan}

1) Membahas profil ekonomi pedesaan sebagai basis perencanaan program pengembangan,

2) Membahas strategi dasar pembangunan pedesaan berwawasan agribisnis, dan

3) Merumuskan kebijaksanaan pengembangan agribisnis secara koprehensif dan integratif.

\section{TINJAUAN PUSTAKA}

Kemajuan masyarakat pertanian dan pedesaan serta kemajuan ekonomi yang berkembang cepat seperti pada kasus di Korea, Jepang dan Vietnam dilatarbelakangi oleh keorganisasian kelompok tani yang relatif kuat. Sistem keorganisasian ekonomi kelompok petani yang mandiri dan kuat dapat mudah dikembangkan bila struktur penguasaan lahan pertaniannya relatif merata.

Meskipun secara ekonomik menguntungkan karena produktivitas yang lebih tinggi dan ongkos yang lebih rendah, tetapi inovasi dalam bentuk usahatani berkelompok bukan merupakan suatu yang bersifat teknis di mana mekanisme yang begitu saja dapat diadopsi oleh petani seperti mengadopsi komponen teknologi fisik (pupuk, pestisida, alat dan lain-lain). Usahatani berkelompok merupakan inovasi yang proses adopsinya melalui suatu proses partisipasi dalam membangun kemampuan kelompok tani untuk mengelola rencana kerja yang telah disusunnya untuk mencapai tujuan bersama.

Perkembangan kelembagaan selayaknya dapat berlangsung secara alamiah. Dalam hal ini campur tangan pemerintah hendaknya bersifat konsultatif fasilitatif dan pengembangan sistem insentif. Pada akhirnya pengembangan dan peranan kelompok tani merupakan perwujudan kekuatan sosial petani berswadaya untuk mencapai kemandirian. Berdasar uraian di atas untuk dapat memanfaatkan sesuatu hal yang secara ekonomi menguntungkan diperlukan suatu bentuk atau organisasi kerja sama yang membuat masyarakat mampu mengembangkan respon yang sesuai dengan logika yang implisit terbawa oleh kondisi atau "iklim" ekonomi yang menguntungkan.

Proses pembangunan (ekonomi) suatu bangsa secara implisit mensyaratkan adanya transformasi pertanian tradisional menjadi pertanian maju atau modern. Dalam proses transformasi itulah pola partisipasi memainkan peranannya. Pertanian maju adalah pertanian yang berkemampuan untuk terus-menerus menyesuaikan diri dengan tantangan dan permintaan pasar yang senantiasa berubah.

Perencanaan kuantitatif ekonomi pertanian Indonesia belum memungkinkan dilakukan selama sektor pertanian (rakyat) belum mampu untuk menumbuhkan partisipasi petani secara menyeluruh. Kekuatan yang menghasilkan momentum untuk membangun itu adalah kemampuan untuk mengelola unit organisasi ekonomi yang cukup "besar" yang dapat berbentuk koperasi kelompok tani atau koperasi agribisnis yang mampu menjalin kerja sama dengan perusahaan (industri) yang mengolah hasil pertanian. Kemampuan manajemen yang didukung oleh partisipasi aktif dari para petani itu merupakan syarat yang diperlukan bagi tumbuh dan berkembangnya industri/perusahaan pertanian (agroindustri) di pedesaan yang terkait secara terpadu dengan kehidupan dan perkembangan usahatani. Dengan demikian akan terbangun suatu pola kemitraan usaha yang saling membutuhkan, memperkuat dan menguntungkan.

Pola kemitraan program pemerintah condong pada pengembangan kemitraan secara vertikal dengan pola hubungan "Bapak Anak Angkat" yang pada agribisnis perkebunan dikenal dengan pola PIR (Perkebunan Inti Rakyat). Sedangkan pola kemitraan pasar berkembang sebagai akibat dari masuknya sistem ekonomi pasar dalam usaha pertanian rakyat di pedesaan. Jenis usaha pertanian yang dibidik adalah usaha tani yang menghasilkan komoditas pertanian bernilai ekonomi tinggi dan mempunyai permintaan kuat di pasar dunia. Pola ini melibatkan petani dengan pemilik modal besar yang bergerak di bidang industri pengolahan dan pemasaran hasil. Mereka menggalang kerja sama ("kemitraan”) karena adanya kepentingan untuk berbagai manfaat ekonomi (mutually beneficial). Pertanian rakyat dapat berdampingan dengan perusahaan besar dengan membina saling ketergantungan di mana petani merasa memiliki perusahaan melalui pemilikan saham. Bentuk kemitraan tersebut mempunyai ciri-ciri sebagai berikut:

1. Petani produsen harus menjadi pemilik saham, sehingga secara kolektif petani menguasai tubuh agribisnis. 
2. Organisasi petani tidak dibatasi hanya pada kegiatan produksi bahan baku.

3. Output usaha pertanian bukanlah bahan mentah yang tidak stabil melainkan komoditas olahan (akhir) dengan nilai tambah tinggi.

4. Hubungan kemitraan antar pelaku agribisnis didasarkan rasionalitas ekonomi dan spesialisasi pembagian kerja secara organik. Azas keterbukaan dan penerapan demokrasi serta pengambilan keputusan baik melalui musyawarah ataupun pemungutan suara (voting).

Dalam rangka membangun kemitraan usaha, diharapkan turut campur pemerintah terutama dalam beberapa aspek yaitu:

1. Mengarahkan kelembagaan ekonomi koperasi, untuk menjadi bagian dari kegiatan agribisnis.

2. Pengkonsolidasian lahan pertanian yang terarah bahwa lahan pertanian adalah untuk usaha pertanian.

3. Pembuatan perangkat hukum (UndangUndang atau PP) yang mendukung berkembangnya kemitraan usaha, terutama yang ditujukan untuk melindungi hak-hak individu petani dari bahaya eksploitasi pemodal besar, dan pengrusakan lingkungan dan sumber daya alam yang menjadi basis usaha di sektor pertanian.

4. Menciptakan prakondisi usaha seperti pengembangan prasarana ekonomi, pengkajian dan penerapan teknologi, kemudahan pelayanan perkreditan, dan pengembangan sistem informasi pasar untuk pengembangan produk pertanian.

Kelembagaan kemitraan usaha agribisnis yang dapat mengeliminir berbagai kegagalan tersebut adalah kelembagaan usaha agribisnis terpadu, berupa keterpaduan antarpelaku (petani, pedagang, pengolah) dan produk (bahan baku berkualitas, penanganan pascapanen yangprima serta jaminan keamanan pangan). Model tersebut didukung oleh revitalisasi kelembagaan kelompok tani, penyuluhan pertanian, dan perusahaan mitra.

Secara tertulis Indonesia telah menganut konsep pembangunan pertanian berkelanjutan. Hal ini termuat dalam amandemen UUD 1945, pasal 33 bahwa "perekonomian nasional diselenggarakan berdasar atas demokrasi ekonomi dengan prinsip kebersamaan, efisiensi, berkeadilan, berkelanjutan, berwawasan lingkungan, kemandirian, serta dengan menjaga keseimbangan kemajuan dan kesatuan ekonomi nasional". Pembangunan berkelanjutan dapat dilakukan dengan pendekatan sistem dan usaha agribisnis serta kemitraan usaha. Dalam agribisnis dikenal konsep agribisnis sebagai suatu sistem dan agribisnis sebagai suatu usaha (perusahaan). Di samping itu dikenal azas-azas dalam pengembangan agribisnis yang berkelanjutan, seperti dikemukakan oleh Sudaryanto dan Hadi (1993) serta Hadi et al. (1994), yaitu terpusat, efisien, menyeluruh dan terpadu, serta menjaga kelestarian lingkungan.

Struktur agribisnis yang berkembang saat ini dapat digolongkan sebagai tipe dispersal atau tersekat-sekat, kurang memiliki daya saing, dan tidak berkelanjutan. Hal itu disebabkan oleh tiga faktor utama (Simatupang 1995), yaitu: 1) tidak ada keterkaitan fungsional yang harmonis diantara kegiatan atau pelaku agribisnis, sehingga dinamika pasar belum dapat direspons secara efektif karena tidak adanya koordinasi, 2) terbentuknya marjin ganda sehingga ongkos produksi, pengolahan, dan pemasaran hasil yang harus dibayar konsumen menjadi lebih mahal, atau sistem agribisnis tidak efisien, dan 3) tidak adanya kesetaraan posisi tawar antara petani dan pelaku agribisnis lainnya sehingga petani sulit mendapatkan harga pasar yang wajar. Ada dua sistem koordinasi, yaitu koordinasi melalui harga pasar dan antarpelaku agribisnis. Operasionalnya dapat dilakukan melalui kelembagaan kemitraan usaha agribisnis. Sistem yang pertama tidak dapat menjamin keterpaduan produk, dan sebaliknya untuk sistem kedua.

Pembangunan pertanian berkelanjutan melalui pendekatan sistem dan usaha agribisnis dan kemitraan usaha memberikan beberapa manfaat sekaligus, yaitu: 1) mengoptimalkan alokasi sumber daya pada satu titik waktu dan lintas generasi, 2) meningkatkan efisiensi dan produktivitas produk-produk pertanian karena adanya keterpaduan produk berdasarkan tarikan permintaan (demand driven), 3) meningkatkan efisiensi masing-masing subsistem agribisnis dan harmonisasi keterkaitan antarsubsistem melalui keterpaduan antar pelaku, 4) terbangunnya kemitraan usaha agribisnis yang saling membutuhkan, memperkuat, dan menguntungkan, dan 5) adanya kesinambungan usaha yang menjamin stabilitas dan kontinuitas pendapatan seluruh pelaku agribisnis.

Efisiensi dan pertumbuhan sektor pertanian dapat dipacu melalui pertumbuhan produksi dan pendapatan petani, pembentukan modal, dan peningkatan daya saing. Pemerataan kepemilikan sumber daya dapat ditempuh melalui kebijakan reformasi agraria (land reform) serta meningkatkan akses dan kontrol masyarakat petani ke sumber daya pertanian, modal, teknologi, kesejahteraan sosial, dan ketenteraman. Kelestarian sumber daya pertanian dan lingkungan dapat diwujudkan dengan mengembangkan sistem usaha tani ramah lingkungan, memelihara dan meningkatkan kualitas lingkungan, mengurangi dampak negatif eksternal, serta mendorong dampak positif eksternal dalam proses pembangunan.

Keberhasilan pembangunan pertanian berkelanjutan ditentukan oleh pelaksanaan revitalisasi pertanian. Krisnamurthi (2006) mengemukakan, revitalisasi pertanian memiliki tiga 
pengertian. Pertama, sebagai kesadaran akan pentingnya per tanian bagi kehidupan bangsa dan rakyat Indonesia, kedua, sebagai bentuk rumusan harapan masa depan tentang kondisi pertanian, serta ketiga, sebagai kebijakan dan strategi besar melakukan revitalisasi itu sendiri.

Pada bahasan ini, revitalisasi dibatasi pada kelembagaan pertanian, yaitu kesadaran untuk menempatkan kembali arti penting kelembagaan secara proporsional dan kontekstual. Bukti empiris menunjukkan, penurunan kinerja kelembagaan penyuluhan pertanian dan kelompok tani pada awal otonomi daerah menjadi salah satu faktor kunci tidak stabilnya produksi pertanian, khususnya padi dan beberapa komoditas palawija.

Kelembagaan kelompok tani perlu pula melakukan konsolidasi, baik dari aspek keanggotaan, manajemen maupun orientasi usaha. Kelembagaan kelompok tani ke depan hendaknya mampu mentransformasikan diri dari kelembagaan usaha tani dalam ikatan horizontal menuju kelembagaan yang berorientasi pasar dan terintegrasi secara vertikal, atau berbentuk koperasi agribisnis yang berbadan hukum.

Alternatif model adalah pembangunan pertanian berkelanjutan melalui kemitraan usaha. Model ini tetap mempertimbangkan berbagai bentuk kelembagaan sebagai penopang kehidupan masyarakat, yaitu kelembagaan yang hidup dan telah diterima oleh komunitas lokal atau tradisional (voluntary sector), kelembagaan pasar atau ekonomi (private sector), dan kelembagaan politik/pemerintah atau sistem pengambilan keputusan di tingkat publik (public sector) (Etzioni 1961). Pengembangan model pembangunan pertanian berkelanjutan melalui kemitraan usaha di pedesaan dengan melakukan revitalisasi kelembagaan kelompok tani dan penyuluhan.

Pemberdayaan petani menjadi petani mandiri dan profesional dapat dilakukan melalui beberapa langkah. Pertama, meningkatkan kualitas sumber daya manusia petani melalui pelatihan, penelitian, magang dan sebagainya, baik secara individu maupun kelompok. Kedua, melakukan revitalisasi kelompok tani mandiri ke arah kelembagaan formal berbadan hukum (koperasi petani atau koperasi agribisnis, asosiasi petani komoditas tertentu). Ketiga, mengangkat penyuluh swakarsa atau petani petandu (dalam program SLPHT) sebagai mitra penyuluh untuk memperlancar difusi dan adopsi teknologi. Keempat, memberdayakan kelembagaan penyuluhan pertanian dan kelembagaan Balai Penyuluhan Pertanian (BPP) menjadi Pusat Pelayanan dan Konsultasi Agribisnis (PPA) di setiap kecamatan melalui sistem penyuluhan partisipatif.

Kelembagaan di tingkat petani seperti kelompok tani yang belum mandiri perlu direvitalisasi sesuai dengan kondisi dan kebutuhan setempat. Jumlah anggota kelompok dibatasi 20-25 orang untuk memudahkan penyatuan pendapat dan penggalangan kerja sama (partisipasi). Hal ini didasarkan pada keberhasilan berbagai program pembangunan pertanian melalui AGRISAMUDRA, Jurnal Penelitian Vol. 2 No. I Januari-Juni 2015 pendekatan kelompok-kelompok kecil dan proses seleksi yang baik, seperti Program Peningkatan Pendapatan Petani dan Nelayan Kecil (P4K) dan SLPHT. Kelompok tani mandiri didorong untuk mengkonsolidasikan diri dalam kelembagaan formal berbadan hukum, sehingga me mudahkan melakukan transaksi dan kemitraan usaha agribisnis.

Kelompok-kelompok tani dapat disatukan dalam bentuk gabungan kelompok tani (gapoktan), asosiasi petani atau asosiasi agribisnis yang anggotanya adalah para pengurus kelompok tani. Ketua-ketua kelompok tani diangkat sebagai penyuluh swakarsa yang bertanggung jawab akan perkembangan kelompoknya. Jika memungkinkan, penyuluh swakarsa mendapat insentif atau honor yang dianggarkan dalam Anggaran Pendapatan dan Belanja Daerah (APBD). Pemahaman terhadap berbagai aspek pembangunan berkelanjutan (ekonomi, sosial, dan lingkungan) merupakan prasyarat untuk menjadi penyuluh swakarsa. Gapoktan atau asosiasi dipimpin oleh seorang ketua atau koordinator penyuluh swakarsa desa (jabatan ini hampir sama dengan Kelompok Tani Nelayan Andalan (KTNA) yang berlaku sekarang). Para penyuluh swakarsa akan menjadi mitra Penyuluh Pertanian Lapang (PPL) dalam mengembangkan pembangunan pertanian berkelanjutan melalui kemitraan usaha agribisnis.

Dalam era otonomi daerah, PPL dan penyuluh swakarsa bertugas di tingkat desa dan berkantor di PPA di tingkat kecamatan. Namun untuk memperlancar tugas, di setiap desa yang menjadi wilayah kerjanya perlu ada sekretariat. Semua bantuan teknis penyediaan infrastruktur fisik, peralatan dan bahan, dana, serta bimbingan teknis disediakan dan dianggarkan pada Anggaran Pendapatan dan Belanja Negara (APBN) maupun APBD. Perma-salahan yang muncul dimusyawarahkan di PPA, namun bila sulit terpecahkan, penyuluh bisa menghubungi dan atau memanggil peneliti/penyuluh BPTP, lembaga penelitian atau perguruan tinggi. Koordinator PPL berfungsi sebagai ketua pelaksana PPA, dan bersama gapoktan dan asosiasi petani atau asosiasi agribisnis merencanakan melaksanakan dan mengevaluasi pengembangan agribisnis pedesaan.

Bila sistem ini berhasil dikembangkan, diharapkan masyarakat petani secara aktif mendatangi PPA untuk mengakses informasi teknologi dan pasar atau berkonsultasi tentang masalah yang dihadapi. Dengan demikian, penyuluhan partisipatif dapat berjalan dengan baik dan petani terdidik untuk bertindak secara profesional. Konsultasi dapat dilakukan secara pribadi atau melalui musyawarah kelompok (sebaiknya diawali dengan musyawarah kelompok, bila tidak teratasi baru dimajukan ke musyawarah gapoktan atau asosiasi petani/asosiasi agribisnis). PPA tidak hanya merencanakan pengembangan agribisnis, tetapi juga memberdayakan dan meningkatkan kualitas sumber daya petani, PPL, dan penyuluh swakarsa, serta sebagai mediator 
bagi terbangunnya kemitraan usaha antar pelaku agribisnis yang saling membutuhkan, memperkuat, dan menguntungkan.

Implementasi pembangunan pertanian berkelanjutan melalui kemitraan usaha agribisnis adalah sebagai berikut. Petani melakukan konsolidasi dalam wadah kelompok tani. Selanjutnya, kelompok tani mandiri ditransformasikan dalam kelembagaan formal berbadan hukum (koperasi pertanian, koperasi agribisnis, atau kelembagaan lainnya sesuai kebutuhan). Kelompok tani mandiri atau kelembagaan berbadan hukum meng konsolidasikan diri dalam gapoktan atau asosiasi petani/asosiasi agribisnis, lalu melakukan konsolidasi manajemen usaha pada hamparan lahan yang memenuhi kelayakan usaha (skala usaha bergantung jenis komoditas, 25-100 ha), serta kesinambungan usaha. Pilihan komoditas atau kelompok komoditas disesuaikan dengan potensi wilayah dan permintaan pasar dengan memperhatikan kelestarian lingkungan.

\section{HASIL DAN PEMBAHASAN}

Salah satu hambatan utama untuk menghasilkan produk pertanian berdaya saing tinggi adalah lemahnya "bangunan" kelembagaan kemitraan agribisnis terutama yang dijalankan oleh dan di masyarakat pedesaan. Dewasa ini sebagian pelaku agribisnis adalah petani di pedesaan dan hampir semuanya merupakan kegiatan usaha tani yang dikelola dengan pola usaha keluarga. Kemitraan usaha yang menonjol di tingkat desa adalah kemitraan horizontal, antara lain berupa kerja sama kelompok tani, sedangkan hubungan buruh-majikan, atau bapak-anak angkat.

Peran kemitraan usaha adalah pada kemampuan kerja sama yang lebih teratur dan terarah, sehingga pengembangan sistem agribisnis mempunyai daya guna yang lebih tinggi dan berdampak positif bagi peningkatan kesejahteraan pelaku-pelaku agribisnis di pedesaan. Dihasilkannya produk pertanian berdaya saing tinggi, dapat dipandang sebagai interaksi sinergis dari komponen budaya material, peran kewirausahaan dan kelembagaan (kemitraan yang terbangun dengan baik). Struktur organisasi ekonomi masyarakat pedesaan sangat rapuh dan hal itu tercermin dari posisi pelaku ekonomi pedesaan yang tidak "memiliki" kekuatan memadai untuk melakukan bargaining position dengan pelaku ekonomi di luar desa. Lemahnya bargaining position tersebut disebabkan oleh banyak faktor, antara lain kelemahan dalam pengorganisasian kelompok tani, penguasaan permodalan usaha, interdependensi yang sangat timpang antar pelaku ekonomi pedesaan dengan luar pedesaan.

Pola keorganisasian kemitraan yang ada dewasa ini, yaitu program pemerintah (inti-plasma), tradisional (patront client) dan pasar ("rasional") masih menempatkan petani pada posisi yang tereksploitasi secara sangat tidak adil. Pola pemerintah menunjukkan terlalu dominannya intervensi pemerintah dan pada umumnya AGRISAMUDRA, Jurnal Penelitian Vol. 2 No. I Januari - Juni 2015 menempatkan plasma pada posisi yang lemah. Pola tradisional sulit menumbuhkan semangat dan kreativitas serta mengembangkan diri, sedangkan pola pasar menyebabkan besarnya ketergantungan petani terhadap usahawan dan dapat menimbulkan konglomerasi. Bagi pengembangan agribisnis "kecil" masalah yang sering dihadapi terutama adalah ketidakseimbangan rebut tawar (bargaining position) dan adanya intransparansi bisnis. Oleh sebab itu peran pemerintah selain sebagai regulator dan pemberi insentif, juga perlu diarahkan untuk membantu pengembangan kegiatan kemitraan usaha agribisnis kecil.

Karakteristik usaha tani di Indonesia dicirikan oleh sifat usaha skala kecil dikelola secara independen dan menyebar dalam kawasan yang luas (dispersal). Konsekuensinya adalah volume produksi terbatas, kualitas produk dan waktu panen bervariasi serta biaya pengumpulan produk relatif besar sehingga kurang kondusif bagi pengembangan agroindustri dan sistem pemasaran yang efisien. Dampak integratifnya adalah tingginya biaya pemasaran sehingga akan menekan pangsa harga yang diterima petani dan mengangkat tingkat harga yang dibayar konsumen. Akibatnya adalah permintaan dan penawaran produk usaha tani akan menurun, sehingga menghambat perkembangan agribisnis.

Berdasarkan pada permasalahan tersebut maka strategi kemitraan usaha yang tepat untuk mendorong mengembangkan agribisnis di pedesaan adalah kemitraan usaha melalui konsolidasi vertikal. Usaha tani skala kecil dikonsolidasikan oleh suatu usaha agroindustri atau pemasaran dalam suatu usaha kemitraan sehingga tercipta satu unit industri pertanian (agroindustri). Pola kemitraan haruslah didasarkan pada kesadaran semua pihak bahwa mereka saling membutuhkan dan hanya dapat tumbuh bersama sehingga harus bermitra dengan prinsip transparan, adil, patuh aturan kesepakatan dan terpercaya.

Pengembangan unit agroindustri merupakan strategi dasar pengembangan agribisnis di pedesaan. Pengembangan unit agroindustri merupakan strategi operasional yang tepat sebagai implementasi dari konsep pengembangan wilayah pedesaan yang tertata (agropolitan). Mengingat pasar tidak selamanya sempurna dan adanya senjang informasi, maka pembentukan agroindustri haruslah dipacu melalui peran aktif pemerintah yang bertindak sebagai inisiator gagasan, mediator, fasilitator, pelindung dan regulator yang jujur, adil dan bijaksana.

Kemitraan adalah kerja sama antara usaha kecil dan usaha menengah atau dengan usaha besar disertai pembinaan dan pengembangan oleh usaha menengah atau besar dengan memperhatikan prinsip saling memerlukan, saling memperkuat dan saling menguntungkan. Untuk menjalin kemitraan, petani perlu disiapkan dalam arti ditingkatkan kemampuannya baik dari aspek keorganisasian, manajemen, dan permodalannya supaya bisa bermitra dengan yang 
lebih kuat. Suatu usaha dapat berkembang dengan baik bila dapat diidentifikasi dengan baik berbagai faktor yang mempengaruhinya baik faktor internal (pendorong dan penghambat) dan eksternal (peluang dan tantangan). Pengembangan kelembagaan kemitrausahaan dapat dipandang sebagai komplemen dari konsolidasi segmensegmen kegiatan pertanian. Pada kelembagaan kemitrausahaan, kegiatan pertanian selain bisa diarahkan untuk meningkatkan pencapaian efisiensi ekonomi, juga bisa untuk tujuan peningkatan pemerataan dan keadilan.

Dengan konsolidasi segmen-segmen kegiatan pertanian "usaha tani" dapat menjadi satu kesatuan dengan industri "pengolahan hasil". Dengan konsolidatif ini, friksi antar kegiatan tersebut dapat ditekan sekecil mungkin. Gejala umum yang tidak sehat seperti harga bahan baku (hasil usaha tani petani) yang ditekan oleh pengusaha pengolah hasil pertanian tidak lagi dijumpai. Peningkatan efisiensi dapat dimulai dari konsolidasi lahan usaha tani, untuk dikelola secara kolektif. Beberapa manfaat adanya konsolidasi usaha tani ini antara lain:

1. Seluruh rangkaian kegiatan fisik dapat diselenggarakan di pedesaan sehingga pengembangan pertanian berimpit dengan pengembangan ekonomi pedesaan.

2. Teknologi dan modal untuk pengembangan pertanian bisa langsung diarahkan dan disalurkan ke pedesaan.

3. Sumberdaya pertanian di pedesaan, misalnya lahan bisa dikelola secara lebih efisien.

4. Mendorong perekonomian desa berkembang lebih pesat, sehingga dapat membendung mengalirnya tenaga-tenaga kerja muda yang potensial dari pedesaan ke kota.

\section{Mengembangkan Agribisnis Konsolidatif}

Ciri-ciri sebagian besar usaha tani Indonesia adalah (1) merupakan usaha keluarga skala kecil sehingga volume produksi per usaha tani sangat kecil, (2) usaha tani dikelola secara independen sehingga kualitas produk yang dihasilkan dan waktu panen bervariasi antar petani; (3) Usaha tani tersebar dalam kawasan luas (dispersal) sehingga biaya pengumpulan hasil produksi besar pula dan juga sistem pemasaran hasil tidak efisien; (4) volume kecil merupakan penghambat eksploitasi skala ekonomi; (5) kualitas yang beragam membuat ongkos standarisasi tinggi; dan (6) tiadanya kepastian informasi mengenai kualitas dan waktu panen menciptakan ongkos pencarian dan risiko kesalahan informasi.

Dengan demikian, strategi yang tepat untuk mendorong perkembangan agribisnis di pedesaan ialah agribisnis konsolidatif, usaha kecil dikonsolidasikan, sehingga sistem ekonomi dualistik yang selama ini mendominasi usaha pertanian di Indonesia dapat dihapuskan. Indikator sehatnya organisasi masyarakat pertanian antara lain mencakup adanya konsolidasi dan integrasi antar cabang agribisnis pertanian, interdependensi antar pelaku agribisnis pertanian dan iklim usaha yang dibangun (praktek persaingan usaha yang sehat, pencegahan praktek monopoli, kemudahan usaha, kepastian hukum dan penyelenggaraan administrasi pemerintah yang bersih dan berwibawa.

Pengembangan agribisnis konsolidatif merupakan konsolidasi secara vertikal dari sejak segmen kegiatan usaha tani, pengolahan hingga pemasaran. Dengan konsolidasi ini kegiatan pertanian "usaha tani" menjadi satu kesatuan dengan industri "pengolahan hasil". Dengan konsolidatif ini, friksi antar segmen kegiatan agribisnis tersebut dapat ditekan sekecil mungkin. Gejala umum yang tidak sehat, seperti harga bahan baku (hasil usaha tani petani) ditekan oleh pengusaha pengolah hasil pertanian, tidak dijumpai lagi.

\section{Strategi Dasar Pengembangan Agribisnis}

Bagian ini akan membahas beberapa hal sebagai berikut: 1) Pendekatan agropolitan dalam pengembangan agribisnis sejalan dengan pelaksanaan otonomi daerah; 2) Pendekatan pengembangan agribisnis berbasis komunitas lokal dengan sasaran efektivitas dan keberlanjutan pelaksanaan program; 3) Pengembangan sistem dan usaha agribisnis secara interatif dalam rangka efektivitas manajemen dan peningkatan daya saing komoditas pertanian; dan 4) Kebijaksanaan strategis sebagai faktor pendukung pengembangan agribisnis di tingkat nasional dan daerah.

\section{Pendekatan Agropolitan Dalam Pengembangan Agribisnis}

Struktur perekonomian wilayah merupakan faktor dasar yang membedakan suatu wilayah dengan wilayah lainnya. Perbedaan tersebut sangat erat kaitannya dengan kondisi dan potensi suatu wilayah dari segi fisik lingkungan, sosial ekonomi dan kelembangaan. Bagi pembangunan wilayah pedesaan dibutuhkan pusat pertumbuhan yang berfungsi sebagai pusat pasar, pelayanan dan pemukiman penduduk, dan sebagai unsur strategis perencanaan dan pelaksanaan pembangunan pedesaan (PSE, 2000).

Pentahapan langkah-langkah operasional yang perlu dipertimbangkan dalam pengembangan agribisnis berbasis komunitas lokal adalah pemilihan lokasi dan mitra pengembangan, pemahaman situasi perencanaan partisipatif, implementasi program yang diikuti oleh aktivitas pemantauan dan evaluasi partisipatif (PSE, 2000). Beberapa langkah operasional laninnya yang secara spesifik perlu dipertimbangkan adalah sebagai berikut: a) Pemilihan dan karakterisasi lokasi dengan sasaran untuk memperkuat, memperdalam dan memperluas kegiatan yang sudah ada; b) Identifikasi permasalahan dan kebutuhan secara intensif, dimana masyarakat didorong untuk memahami dan merumuskan pemecahan masalah yang mereka hadapi; dan c) 
Pengkajian dan diseminasi teknologi secara partisipatif yang mengikuti alur kegiatan dalam kelompok kecil dan bersifat informal, pemecahan permasalahan secara kolektif, dan memperkuat hubungan secara horizontal.

\section{Restrukturisasi dan Konsolidasi Agrisbisnis}

Dalam rangka menempatkan sektor pertanian menjadi andalan pengembangan perekonomian rakyat dan pedesaan, maka perlu ditempuh langkah-langkah untuk merubah struktur agribisnis yang ada. Dalam hal ini, paling tidak terdapat empat langkah penting yang perlu ditempuh (PSE, 1999), yaitu: a) Penghapusan struktur ekonomi yang dualistik, b)Pengembangan agribisnis spesifik lokasi, c) Pengembangan agribisnis konsolidatif, dan d) Pengembangan kelembagaan kemitraan usaha.

Karakteristik usahatani rakyat dicirikan oleh sifat usaha kecil, pengelolaan independen, dan menyebar dalam kawasan yang luas (dispersal). Konsekwensinya adalah volume produksi terbatas, kwalitas produk dan waktu panen bervariasi, dan biaya pengumpulan produk relatif besar sehingga kurang kondusif sebagai basis pengembangan agroindustri dan sistem pemasaran yang efisien. Dampak integratifnya adalah tingginya biaya pemasaran sehingga akan menekan pangsa harga yang diterima petani dan mengangkat tingkat harga yang dibayar konsumen. Akibatnya adalah permintaan dan penawaran produk usahatani akan menurun, sehungga menghambat perkembangan bisnis.

Berdasarkan pada permasalahan tersebut maka strategi yang tepat untuk mendorong perkembangan agribisnis di pedesaan adalah konsolidasi vertikal. Usahatani skala kecil dikonsolidasikan oleh suatu usaha agroindustri atau pemasaran dalam suatu organisasi usaha kemitraan sehingga tercipta satu unit agribisnis industrial. Pola kemitraan haruslah didasarkan pada kesadaran semua pihak bahwa mereka saling membutuhkan dan hanya dapat tumbuh bersama sehingga harus bermitra dengan prinsip transparan, adil, patuh aturan kesepakatan, dan terpercaya. Pengembangan unit agribisnis industrial merupakan strategi dasar pengembangan agribisnis di pedesaan. Pengembangan unit agribisnis indutrial merupakan strategi operasional yang tepat sebagai implementasi dari konsep agropolitan yang diuraikan sebelumnya. Mengingat pasar tidak sepenuhnya sempurna dan adanya senjang informasi, maka pembentukan agribisnis industrial haruslah dipacu melalui peran aktif pemerintah yang bertindak sebagai inisiator gagasan, mediator, fasilitator, pelindung dn regulator yang jujur, adil, dan bijaksana. Forum dialog antara pengusaha, petani, dan pemerintah dinilai sangat penting dalam mencapai keberhasilan program kemitraan agribisnis industrial di pedesaan.

\section{Kebijakan Strategis Pengembangan Agribisnis}

Operasional paradigma pembangunan ekonomi pedesaan berlandaskan agribisnis (PEPEBA) membutuhkan dukungan paket kebijakan komprehensif dan terpadu yang meliputi enam program utama yaitu: a) Pembangunan infrastruktur ekonomi pedesaan, b) Pengembangan sistem inovasi pertanian, c) Pengembangan kelembagaan petani, d) Optimasi sumberdaya berkelanjutan, e) Pemacuan investasi, dan f) Kebijakan insentif.

Keenam program utama tersebut merupakan satu kesatuan yang saling komplemeter dan sinergis. Dengan bidang cakupan yang demikian luas maka jelas kiranya bahwa penanggung jawab pelaksanaan program-program tersebut berada dalam departemen dan dinas pemerintahan yang berbeda. Oleh karena itu, koordinasi, integrasi, dan sinkronisasi merupakan kunci utama untuk keberhasilan operasionalisasi paket program tersebut. Di tingkat nasional, peranan Kantor Menteri Koordinator Bidang Perekonomian dan Badan Perencanaan Pembangunan Nasional (BAPPENAS) merupakan kunci bagi kelayakan operasional paradigma pembangunan ini. Sedangkan di tingkat Propinsi dan Kabupaten, institusi kunci ialah Badan Perencanaan Pembangunan Daerah (BAPPEDA). Pembangunan infrastruktur membutuhkan anggaran pembangunan yang sangat besar sehingga mesti mendapatkan dukungan politik dari DPR dan DPRD. Oleh karena itu, paradigma PEPEBA hanya dapat dilaksanakan apabila telah ada konsensus nasional.

\subsection{Pembagunan Infrastruktur Ekonomi Pedesaan}

Adanya infrastruktur ekonomi yang memadai merupakan prakondisi bagi tumbuhkembangnya kegiatan agribisnis dan perekonomian secara umum di pedesaan. Infrastruktur yang sesuai bagi agribisnis dan perekonomian desa secaara umum ialah: a) Sistem pengairan, b) Pasar komoditas pertanian, c) Jalan raya, d) Kelistrikan, e) Jaringan telekomunikasi. Infrastruktur tersebut merupakan barang publik (public good) atau semi publik (semi public good) sehingga pembangunannya harus diselenggarakan oleh pemerintah atau pemerintah bersama-sama dengan masyarakat (swasta). Pembangunan infrastruktur merupakan tanggung jawab pemerintah yang paling strategis dalam operasionalsasi paradigma PEPEBA.

Walaupun dalam volume, kualitas dan waktu yang berbeda, setiap tanaman dan hewan mutlak membutuhkan air. Agroindustri juga membutuhkan air yang cukup. Bagi usaha pertanian, sistem irigasi berguna untuk (a) Meningkatkan produktivitas lahan, (b) Mningkatkan intensitas tanaman, (c) Meningkatkan potensi diversifikasi pengunaan lahan.Usaha peternakan membutuhkan air bersih dan sistem pengairan yang mengalir. Usaha perikanan membutuhkan air yang subur dan mengalir. Agroindustri membutuhkan air bersih dan sistem penyaluran limbah. Secara umum, sistem pengairan 
merupakana syarat esensial bagi pembangunan agribisnis di pedesaan.

Sumber air, seperti sungai dan danau, merupakan milik bersama masyarakat (common property). Pembangunan jaringan irigasi skala besar membutuhkan dana investasi yang sangat besar. Oleh karena itu, pembangunan sistem pengairan haruslah diselenggarakan oleh pemerintah atau oleh masyarakat lokal secara bersama-sama. Mengingat keterbatasan anggaran pembangunan pemerintah maka alternatif lain yang dapat ditempuh ialah mendorong petani dan pengusaha membangun sumber pengairan sendiri seperti pompa air tanah, jaringan irigasi sederhana swakelola.

Pasar lokal komoditas pertanian juga sangat essensial bagi tumbuh-kembangnya agribisnis di pedesaan. Pembangunan pasar lokal sangat diperlukan untuk menjamin bahan produk yang dihasilkan petani dapat terjual dengan harga wajar. Pembangunan pasar lokal berfungsi menciptakan pasar komoditas pertanian yang efisien. Pasar lokal juga merupakan barang publik yang mesti dibangun dan dikelola pemerintah. Jalan raya diperlukan untuk membuka perekonomian desa sehingga tercipta perdagangan dengan perekonomian di luar desa. Sistem jalan raya yang efeisien sangat diperlukan untuk meminimumkan biaya pemasaran. Sistem jalan raya yang efisien mutlak diperlukan bagi pertumbuhan dan perkembangan agribisnis. Jalan raya merupakan barang publik yang mesti dibangun dan dipelihara oleh pemerintah.

Kelistrikan merupakan sumber tenaga dan penerangan yang sangat essensial untuk agroindustri serta berbagai alat dan mesin pertanian. Pembangunan kelistrikan pedesaan sangat diperlukan untuk memacu pertumbuhan dan perkembangan agribisnis, perekonomian desa secara umum dan kenyamanan hidup penduduk pedesaan, kelestrikan pedesaan dapat dibangun oleh pemerintah atau oleh perusahaan swasta. Namun demikian, mengingat peran strateginya, inisiatif dan tanggung jawab utama pembangunan kelistrikan swasta pedesaan perlu didorong dalam rangka mempercepat perluasan penyebaran kelistrikan di pedesaan. Jaringan telekomunikasi diperlukan untuk memperlancar lalulintas informasi antara desa dan luar desa.

Jaringan telekomunikasi bermanfaat untuk mengurangi distorsi informasi pasar dan teknologi. Telekomunikasi yang cepat, tepat dan murah dapat mengurangi biaya transaksi. Dengan demikian, pembangunan jaringan telekomunikasi pedesaan essensial untuk menumbuhkembangkan agribisnis dan perekonomian desa secara umum. Telekomunikasi mengandung skala ekonomi yang besar sehingga akan lebih efisien apabila dibangun oleh Badan Usaha milik Negara (BUMN). Namun demikian, investasi swasta pada usaha jasa telekomunikasi di pedesaan juga perlu dirangsang pemerintah sehingga perkembangannya lebih ceapat dan pasarnya efisien.

AGRISAMUDRA, Jurnal Penelitian Vol. 2 No. I Januari - Juni 2015
Pengembangan Sistem Inovasi Pertanian

Organisasi petani yang perlu dikembangkan meliputi: a) Organisasi untuk mengatur sumberdaya milik bersama seperti: organisasi petani pengguna air, pemanfaatan hutan atau lahan adat, dan sebagainya, b) Organisasi bisnis kooperatif yang dapat berupa kegiatan kolektif (pembelian sarana produksi, kolektif, pengadaan modal kolektif dan pemasaran hasil kolektif), usaha bersama (kongsi) dan koperasi, c) Organisasi lobi politik-ekonomi dengan membentuk paguyuban petani.

\section{Optimasi Sumberdaya Berkelanjutan}

Usaha pertanian pada dasarnya berbasis pada sumberdaya alam yang meliputi tanah, air, iklim dan genetika. Apabila tidak dikelola dengan bijaksana, eksploitasi sumberdaya tersebut dapat merusak kapasitas pemilikannya sehingga potensi produksinya akan menurun dan basis produksi usaha pertanian akan menurun pula. Produktivitas usahapun akan menurun, yang berarti daya saingnya menurun pula. Dengan perkataan lain, usaha pertanian tidak dapat bertahan secara berkelanjutan. Oleh karena itu, pengelolaan sumberdaya pertanian haruslah dilakukan secara optimal.

Optimasi sumberdaya berkelanjutan ialah pola pemanfaatan sumberdaya alam berdasarkan lima prinsip dasar: (a) pertumbuhan, (b) efisiensi, (c) stabilitas, (d) berkelanjutan, dan (e) keadilan yang merata. Dengan prinsip dasar ini maka agribisnis akan dapat tumbuh-berkembang secara berkelanjutan. Optimasi sumberdaya berkelanjutan tak lain ialah pembangunan agriisnis berkelanjutan (sustainable agribusniss development).

\section{Pemacuan Investasi}

Kebijakan pemerintah yang dapat memacu invesstasi pada bidang agribisnis di pedesaan diantaranya ilaha: a) Penyediaan kredit investasi jangka panjang. Hal ini dapat dilakukan antara lain dengan menerapkan penentuan alokasi kredit perbankan oleh Bank Indonesia, b) Penyediaan modal awal (seed capital). Pemerintah menyediakan modal awal dalam pembentukan agribisnis baru yang nantinya harus dikembalikan secara bertahap setelah perusahaan dapatt tumbuh mandiri, c) Pengembangan modal ventura. Pemerintah membentuk perusahaan modal ventura yang akan bertindak sebagai mitra usaha bagi perusahaan agribisnis di pedesaan, d) Pengembangan lembaga perkreditan pedesaan dan bank khusus agribisnis. Pengembangan lembaga perkreditan pedesaan dan bank khusus agribisnis sangat perlu sebagai sumber dana investasi dan modal kerja bagi agribisnis di pedesaan. Bank umum komersial yang sebagian besar berada di perkotaan kurang tertarik menyalurkan dana bagi agribisnis di pedesaan.

\section{Kebijakan Insentif}


Pengusaha agribinis dan penduduk pedesaan secara umum memiliki kekuatan politik yang relatif rendah dibanding dengan pengusaha non-agribisnis dan penduduk perkotaan. Kebijakan pemerintah seringkali cenderung bias menguntungkan pengusaha non-agribisnis dan penduduk perkotaan. Kebijakan harga, perdagangan, fiskal dan moneter seringkali merugikan dan menghambat pertumbuhan agribisnis, lebih-lebih yang berlokasi di pedesaan. Di sisi lain, pemerintah terhadap produk-produk agribisnis pada umumnya tidak elastis sehingga harganya cenderung menurun secara sekuler. Perpaduan antara dampak kebijakan pemerintah dan sifat intrinsik produk agribisnis menyebabkan nilai tukar (terms of trade) petani dan agribisnis secara umum cenderung menurun secara sekuler sehingga menghambat pertubuhan agribisnis di pedesaan.

\section{KESIMPULAN DAN IMPLIKASI KEBIJAKAN}

1. Pembangunan pertanian berwawasan agribinsis yang berkelanjutan dalam perspektif desentralisasi dan otonomi daerah perlu dihela oleh sumberdaya modal, SDM yang handal, dan pengembangan potensi teknologi secara dinamis. Dalam perumusan perencanaan dan implementasinya perlu dipahami profil dan dinamika ekonomi pedesaan, konsepsi dan strategi pengembangannya dan kebijaksanaanpendukung secara komprehensip dalam operasionalnya di lapangan.

2. Fokus pembangunan nasional pada sektor agribisnis dinilai sejalan dengan struktur perekonomian saat ini dan diyakini akan mampu memacu pertumbuhan, pemerataan dan keberlanjutan pemabngunan nasional.

3. Daerah pedesaan dikembangkan berdasarkan pewilayahan komoditas unggulan utama yang menghasilkan bahan baku pengembangan agroindustri di daerah perkotaan. Satuan usaha pengembangan diorganisasikan ke dalam koperasi, perusahaan kecil dan menegah, dengan mempertimbangkan konsepsi pengembangan sebagai berikut: (a) Perkembangan kelembagaan usaha dilakukan melalui insentif dan tidak perlu dicampuri oleh pemerintah; (b) Selain berfungsi sebagai pusat agribisnis, kota juga berfungsi sebagai pusat pelayanan agribisnis yang kompetitif; (c) Lokasi dan sistem transportasi agroindustri dan pusat pelayanan harus memungkinkan para petani untuk bekerja sebagai pekerja paruh waktu; (d) Pusat agroindustri juga berfungsi sebagai pusat pengembangan sumberdaya manusia untuk teknologi yang berkaitan dengan komoditas utama, dan (e) Perkembangan institusional selayaknya dapat berlangsung secara ilmiah, kalaupun ada campur tangan pemerintah hanya dalam bentuk insentif dan disentif.

\section{DAFTAR PUSTAKA}

---. 2000. Pengembangan Agribisnis Berbasis Komunitas Lokal. Makalah Rapat Kerja
Badan Litbang Pertanian, 26-27 Oktober 2000, Jakarta. Pusat Penelitian Sosial Ekonomi Pertanian. Bogor

Adnyana, M.O. 2005. Lintasan dan Marka Jalan Menuju Ketahanan Pangan Terlanjutkan

Badan Litbang Pertanian. 2000. Rumusan Sidang Kelompok Raker Badan Litbang Pertanian, 26-27 Oktober 2000. Jakarta.

Clark, R.J. 1996. Coastal Zone Management Hand Book. CRC Lewis Publishers, Boca Raton, Florida. 694 pp.

Departemen Ekonomi Sumberdaya dan Lingkungan, Fakultas Ekonomi dan Manajemen, Institut Pertanian Bogor, 10 November 2007.

Etzioni, A. 1961. A Competitive Analysis of Complex Organization: on Power, Involve-ment, and Their Correlates. The Free Press of Glencoi, Inc., New York.

Fauzi, A. 2006. Ekonomi Sumber Daya Alam dan Lingkungan: Teori dan aplikasi. Gramedia Pustaka Utama, Jakarta.

Fauzi, A. 2007. Economic of Nature's Non-Convexity Reorientasi. Pembangunan Ekonomi Sumberdaya Alam dan Implikasinya bagi Indonesia. Orasi IImiah Guru Besar IImu Ekonomi Sumberdaya Alam dan Lingkungan,

Food and Agriculture Organization. 1989. World. The State of Food and Agriculture. Food and Agriculture Organization of the United Nations, Rome, Italy.

Gunardi. 1980. Kumpulan Bahan Bacaan DasarDasar Penyuluhan Pertanian. Institut Pertanian Bogor, Bogor.

Hadi, P.U., R. Sajuti, Saptana, Erwidodo, M. Rachmat, Kh.M. Noekman, dan A. Djauhari. 1994. Analisa Kebijaksanaan Pengembangan Agribisnis Perikanan dan Hortikultura: Model Pengembangan Agribisnis Mangga. Pusat Penelitian Sosial Ekonomi Pertanian, Bogor.

Kasryno, F. 2000. Menempatkan Pertanian Sebagai Basis Ekonomi Indonesia: Memantapkan Ketahanan Pangan dan Mengurangi Kemiskinan. Widyakarya Nasional Pangan dan Gizi VII. Lembaga IImu Pengetahuan Indonesia, Jakarta.

Krisnamurthi, B. 2006. Revitalisasi Pertanian: Sebuah konsekuensi sejarah dan tuntutan masa depan. Dalam Revitalisasi Pertanian dan Dialog Peradaban. Penerbit Buku Kompas. Jakarta.

Nasution, L.I. 1998. Pendekatan Agropolitan dalam Rangka Penerepan Pembangunan Wilayah dan Pedesaan. PWD-PPS IPB.

PSE. 2000. Pembangunan Ekonomi Pedesaan Berdasarkan Agribisnis. Pusat Penelitian Sosial Ekonoomi Pertanian. Bogor.

Pusat Penelitian dan Pengembangan Sosial Ekonomi Pertanian bekerja sama dengan BAPPENAS/ USAID/DAI. Bogor.

Ravallion, M. and G. Datt. 1996. How Important to India's Poor is The Sectoral Composition of 
Economic Growth/World Bank Economic Review 10: 1-25.

Rusastra, I.W. dan T. Sudaryanto. 1998. dinamika Ekonomi Pedesaan dalam Perspektif Pembangunan Nasional. Prosiding Dinamika Ekonomi Pedesaan dan Peningkatan Daya Saing Sektor Pertanian. Pusat Penelitian Sosial Ekonomi Pertanian, Bogor.

Sanim, B. 2006. Analisis Ekonomi Lingkungan dan Audit Lingkungan. Makalah disampai-kan pada Pelatihan Dosen Perguruan Tinggi Negeri Se-Jawa dan Bali dalam Bidang Audit Lingkungan, Bogor, 11-20 September 2006.

Saptana dan T. Pranadji. 1994. Dampak Kapitalisasi terhadap Sustainabilitas Pertambakan Udang. Makalah disampaikan pada Seminar Nasional Pengembangan Agribisnis Bidang Peternakan dan Perikanan pada Pelita VI dalam rangka Dies Natalis ke-30 Fakultas Peternakan Universitas Diponegoro, Semarang.

Saptana, E.L. Hastuti, K.S. Indraningsih, Ashari, S. Friyatno, Sunarsih, dan V. Darwis. 2005. Pengembangan Model Kelembagaan Kemitra-an Usaha yang Berdaya Saing di Kawasan Sentra Produksi Hortikultura. Pusat Peneliti-an dan Pengembangan Sosial Ekonomi Per-tanian, Bogor.

Saptana. 2003. Efisiensi dan Daya Saing Usaha Tani Beberapa Komoditas Pertanian di Lahan Sawah Kabupaten Sidrap, Sulawesi Selatan. Pusat Penelitian dan Pengembangan Sosial Ekonomi Pertanian bekerja sama dengan BAPPENAS/ USAID/DAI. Bogor.

Saptana. 2003. Efisiensi dan Daya Saing Usaha Tani Beberapa Komoditas Pertanian di Lahan Sawah Kabupaten Sidrap, Sulawesi Selatan.

Sayogyo. 1990. Manusia dan Produktivitas Pertanian Penopang Lepas Landas Kita. Prisma No.2 Tahun XIX. LP3ES, Jakarta.

Simatupang, P. 1995. Industrialisasi Pertanian sebagai Strategi Agribisnis dan Pembangunan Pertanian dalam Era Globalisasi. Orasi Pe-ngukuhan Ahli Peneliti Utama Bidang Sosial Ekonomi Pertanian. Badan Penelitian dan Pengembangan Pertanian, Jakarta.

Sudaryanto, T. dan P.U. Hadi. 1993. Konsepsi dan lingkup agribisnis. Makalah Seminar Pusat Penelitian Sosial Ekonomi Pertanian, Bogor.

Sutopo, M.F. 1995. Serasah Ekonomi Sumber Daya Hutan Tropis Indonesia. Institute for Islamic Economics Studies, Yayasan Khoiru Ummah, Bogor.

Syahyuti. 2006. 30 Konsep Penting dalam Pembangunan Pedesaan, Penjelasan tentang “Konsep, Istilah, Teori dan Indikator serta Variabel". PT Bina Rena Pariwara, Jakarta.
Turner, P.K., D. Pearce, and I. Bateman. 1993. Environmental Economic: An elementary introduction. John Hopkins University Press, Baltimore.

Worldwatch Institute. 2005. Vital Sign 2005. NN Norton and Company, New York.

Yusdja, Y., C. Saleh, M. Amir, dan Al Sri Bagyo. 1992. Studi Baseline Aspek Sosial Ekonomi Pengendalian Hama Terpadu. Kerja Sama Pusat Penelitian Sosial Ekonomi Pertanian dengan Badan Perencanaan Pembangunan Nasional. Monograph Series No. 6. Pusat Penelitian Sosial Ekonomi Pertanian, Bogor. 